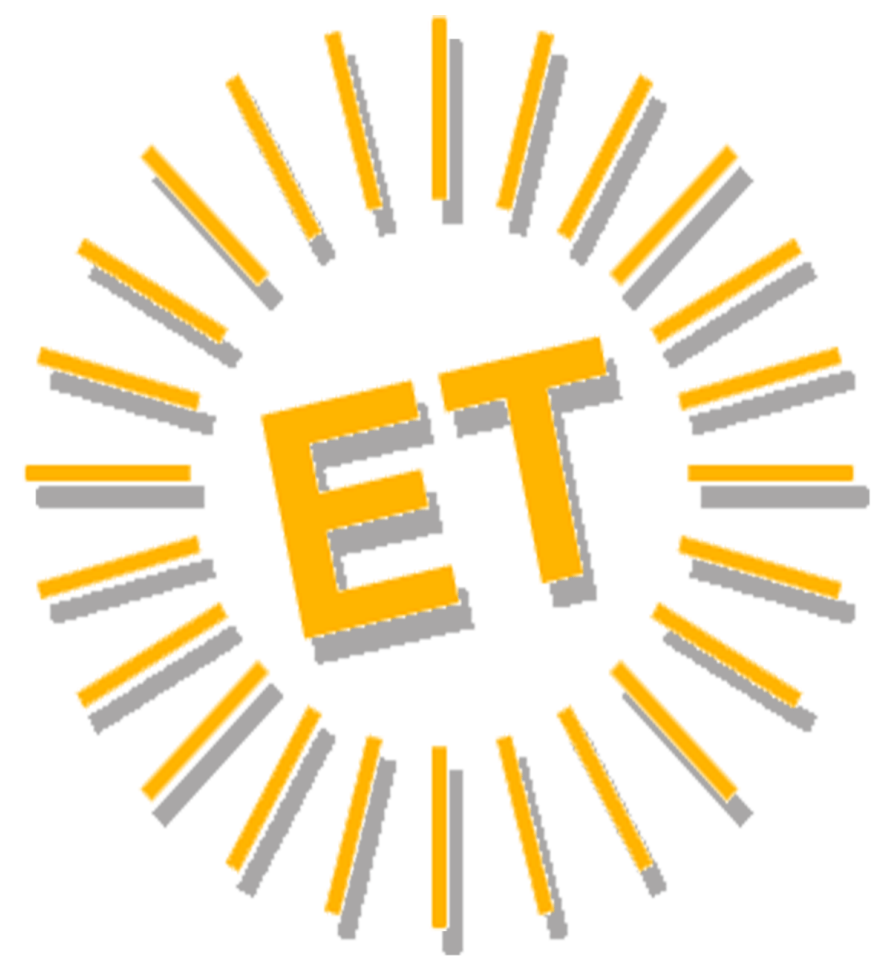




\section{Editorial Team}

\section{Editor in Chief}

Alfonso Vargas-Sánchez, University of Huelva, Spain

\section{Associate Editor}

Mirko Perano, Reald University College, Albania

\section{Books Review Editor}

Brendan Paddison, York St. John University, United Kingdom

\section{Secretariat}

Elena García de Soto, University of Huelva, Spain

Cinta Borrero-Domínguez, University of Huelva, Spain

\section{Style reviewer and text editor}

Anestis Fotiadis, I-SHOU University, Taiwan, Province of China

\section{Editorial Board}

José Manuel Alcaraz, Murdoch University, Australia Mario Castellanos-Verdugo, University of Seville, Spain José Antonio Fraiz-Brea, University of Vigo, Spain José Manuel Hernández-Mogollón, University of Extremadura, Spain

Tzung-Chen Huan, National Chiayi University, Taiwan, Province of China

Shaul Krakover, Ben Gurion University, Israel Jean Pierre Levy-Mangin, University of Quebec, Canada Tomás López-Guzmán, University of Córdoba, Spain Yasuo Ohe, Chiba University, Japón María de los Ángeles Plaza-Mejía, University of Huelva, Spain Nuria Porras-Bueno, University of Huelva, Spain João Albino Silva, Algarve University, Portugal

\section{Advisory Board (Spanish Members)}

Juan Manuel Berbel-Pineda, Pablo de Olavide University, Spain César Camisón-Zornoza, Uniersity of Valencia, Spain Enrique Claver-Cortés, University of Alicante, Spain María Teresa Fernández-Alles, University of Cádiz, Spain José Luis Galán-González, University of Seville, Spain Félix Grande-Torraleja, University of Jaén, Spain

Antonio Leal-Millán, University of Seville, Spain Inmaculada Martín-Rojo, University of Málaga, Spain Antonio Manuel Martínez-López, University of Huelva, Spain Francisco José Martínez-López, University of Huelva, Spain Pablo A. Muñoz-Gallego, University of Salamanca, Spain
Francisco Riquel-Ligero, University of Huelva, Spain José Miguel Rodríguez-Antón, Autonomous University of Madrid, Spain

Sandra Sanchez-Cañizares, University of Cordoba, Spain Josep Francesc Valls-Giménez, ESADE, Spain

\section{Advisory Board (Other European Members)}

Tindara Abbate, University of Messina, Italy Paulo Aguas, University of Algarve, Portugal Carlos Costa, Aveiro University, Portugal Dianne Dredge, Aalborg University, Denmark Salvatore Esposito de Falco, University of Rome "La Sapienza", Italy

Sheila Flanagan, Dublín Institute of Technology, Ireland Tania Gorcheva, Tsenov Academy of Economics, Bulgaria Tadeja Jere Jakulin, University of Primorska, Slovenia Metin Kozak, Mugla University, Turkey Álvaro Matias, Lusiada University, Portugal Alfonso Morvillo, National Research Council, Italy Alexandru Nedelea, Stefan cel Mare University of Suceava, Romania

Claudio Nigro, University of Foggia, Italy

Angelo Presenza, University "G. D'Annunzio" of Chieti-Pescara, Italy

Kanes Rajah, Royal Agricultural University, United Kingdom

\section{Advisory Board (Members from the rest of the world)}

John Allee, American University of Sharjah, United Arab Emirates

Nestor Pedro Braidot, National University of La Plata, Argentina

Roberto Elias Canese, Columbia University, Rector, Paraguay

Luca Casali, Queensland University of Technology, Australia Nimit Chowdhary, Indian Institute of Tourism and Travel Management, India

Steven Chung-chi Wu, National Pingtung University of Science and Technology, Taiwán

Dianne Dredge, Southern Cross University, Australia Daniel Fesenmaier, Temple University, United States

Babu George, Alaska Pacific University, United States Dogan Gursoy, Washington State University, United States Jafar Jafari, University of Wisconsin-Stout, United States Sanggun Lee, Pai Chai University, Korea Republic of Albert Yeh Shangpao, I-SHOU University, Taiwán Pauline Sheldon, University of Hawaii, United States Germán A. Sierra-Anaya, University of Cartagena de Indias, Rector, Colombia Xiaohua Yang, University of San Francisco, United States 


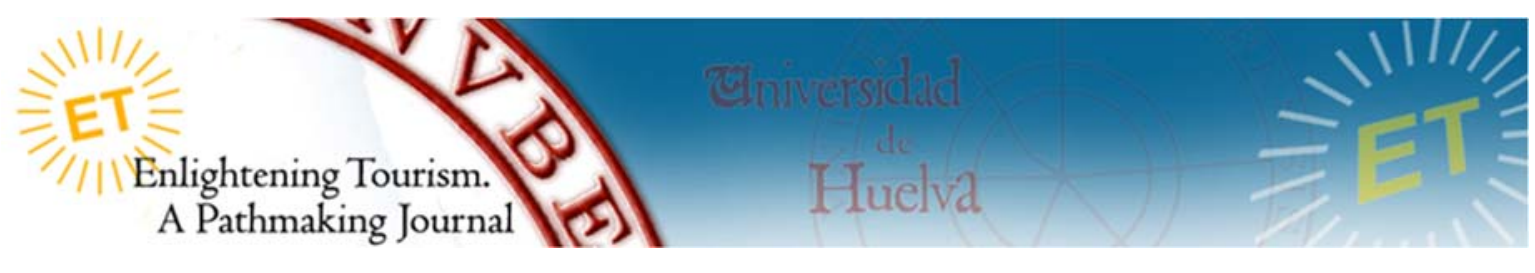

\title{
DIMENSIONS OF A MEMORABLE FOOD AND RESTAURANT EXPERIENCE IN MOUNTAINOUS DESTINATIONS: AN INTERPRETIVE STRUCTURAL MODELING APPROACH
}

\author{
Devkant Kala \\ University of Petroleum \& Energy Studies (India) \\ devkala@gmail.com
}

\begin{abstract}
The present study attempts to determine the factors of memorable food and restaurant experience (MFRE) and model the interrelationships among them using interpretive structural modeling (ISM) in the mountainous destination. Variables of MFRE were identified through literature review, discussion with tourism \& hospitality academicians and practitioners, and tourists visited the mountainous destinations of Uttarakhand, India. The results reveal that restaurant location, decoration, and service employee attributes were bottom-level variables in the model. Service quality, authentic local food, traditional food preparation, and hygiene \& cleanliness were considered as middle-level variables. Authentic food presentation, food quality, and Physical environment experience were top-level variables in MFRE. This work endorses that destination restaurants should offer authentic foods, engage visitors with traditional food preparation \& presentation, focus on food and service quality, maintain the hygienic servicescape, concentrate on staff appearance, decoration, and restaurant location to deliver memorable food and restaurant experience (MFRE) in the mountainous destinations.
\end{abstract}

\section{KEYWORDS}

Memorable food and restaurant experience (MFRE), food \& restaurant attributes, interpretive structural modeling (ISM), mountainous destination, India. 
ECONLIT KEYS

M10; M30; L83; Z33.

\section{INTRODUCTION}

A paradigm shifted from service economy to the experience economy that emphasizes on an outstanding touristic experience can easily be witnessed in tourism (Oh, Fiore, \& Jeoung, 2007; Kim, Ritchie, \& McCormick, 2012). Since travelers devote considerable time on choosing the restaurant, where authentic culinary attributes can be experienced with happiness, several researchers (Björk \& Kauppinen-Räisänen, 2016; Sthapit, 2017; Kala, 2020) advocated that food-related characteristics of a destination significantly shapes the unique touristic experience. Besides the essential physiological requirement, gastronomic elements build a social connection between travelers and community members, develop their understanding about the indigenous foods, conveys symbolic cultural inferences, cultivate the emotional association with a destination, and increase destination attractiveness (Quan \& Wang, 2004; Kivela \& Crotts, 2006; Gross and Brown, 2008; Chang, Kivela, \& Mak, 2011; Hendijani, 2016). Moreover, spending on food during a holiday constitutes a significant travel expenditure (Telfer \& Wall, 2000; Kivela \& Crotts, 2006). Everett (2016) and Stone et al. (2018) suggested that travelers are deliberately and enthusiastically involved in a range of food and restaurant experiences. This positive involvement determines the touristic experience, forms the destination image, encourage revisit intention, develops the competitive advantage, and stimulate growth in associated economic sectors (Chi et al., 2013; Björk \& Räisänen, 2016; Hendijani, 2016; Seo, Yun \& Kim, 2017).

Although memorable food attributes have been examined in several countries, for instance, USA (Ryu, Lee \& Kim, 2012; Stone, et al., 2018), China (Chang et al., 2011; Kim, 2014), Hong Kong (Kivela \& Crotts, 2006), UK (Sims, 2009; Stone, et al., 2018), South Korea (Seo, Yun \& Kim, 2017), Malaysia (Karim \& Chi, 2010; Chi et al., 2013), Indonesia (Hendijani, 2016), and Finland (Björk \& Kauppinen-Räisänen, 2016; Sthapit, 2017), the limited studies (Kala, 2020; Kala \& Barthwal, 2020; Piramanayagam et al., 2020) have been undertaken in the Indian context, particularly in the mountain destinations. The major reason for this attitude is that such attributes have been believed as a secondary factor of the destination rather than an attraction by itself. 
Previous researches (Björk \& Kauppinen-Räisänen, 2016; Hendijani, 2016; Sthapit, 2017; Stone, et.al. 2018) highlighted the need for examining the factors that constitute memorable food and restaurant experience (MFRE) and their relationships in the context of developing countries. This research is more justified for the reason that India, with 247 billion USD, was ranked eighth in terms of the travel \& tourism sector's total contribution to GDP in 2018 (WTTC, 2019). As per the statistics of the Indian Ministry of Tourism, foreign tourist arrivals and domestics tourist visits recorded positive trends. During 2019, foreign tourist arrivals (FTAs) in India stood at 10.89 million, achieving a growth rate of $3.1 \%$. About 1854.93 million domestic tourists visited the various parts of India in 2018, an increase of $11.91 \%$ from the year before. Regarding mountainous destinations, UNEP (2007) stated that mountain areas generate $15-20 \%$ of annual global tourism and are second only to coasts and islands as popular destinations. Besides agriculture and pastoralism, food-related occupation is one of the main businesses of residents in these geographically disadvantaged areas (Kala \& Barthwal, 2020). Considering the central role of gastronomic attributes (food and restaurant) in creating touristic experiences, generating of job opportunities, and enhancing the destination attractiveness, the present study aims to identify the dimensions of MFRE and establish the relationships that exist among them in the mountainous destination. This investigation would be able to make tourism planners and restaurateurs understand the relationship between various attributes of food and restaurant and thus, design strategies to enhance touristic experiences. To understand the relationship between MFRE variables, interpretive structural modeling (ISM) is considered appropriate for the present research.

\section{THEORETICAL FRAMEWORK}

\section{1) MEMORABLE TOURISM EXPERIENCE (MTE) RESEARCH}

Pine and Gilmore (1998) advocated that authentic experiences in the current experience economy have become mainstream in tourism. Tourism researchers have 
pointed out that these complex (Neuhofer, Buhalis, \& Ladkin, 2014), inherently personal (Kim, Ritchie, \& McCormick, 2012), and uniquely memorable experiences (Tung \& Ritchie, 2011) have become more relevant for the tourism sector recently (Stahpit \& Coudounaris, 2018). MTE is composed of those meaningful activities that are recalled and particularly recreated by the visitor when explaining a holiday experience (Tung \& Ritchie, 2011). Piqueras-Fiszman and Jaeger (2015) explained that a memorable experience is related to a positive feeling and is emotionally remembered. Memorable tourist experiences are a more influential driver of future behavior in terms of revisit intention, favorable word-of-mouth, referrals, and tourists' willingness to pay premium prices (Tung \& Ritchie, 2011; Chandralal \& Valenzuela, 2013). Hence, the marketing and competitive implications of MTE make such researches more relevant.

Identifying four important aspects of memorable experience (affect, expectations, consequentiality, and recollection), Tung and Ritchie (2011) recommended that tourism planners and practitioners must deliver promises, unimagined happiness, and stimulate "memory-points" to promote 'must-see' to enhance the tourist experience. Categorizing 24 items into seven dimensions, Kim et al. (2012) developed a widely accepted MTE scale. Similarly, Chandralal and Valenzuela (2013) revealed ten experiential dimensions for strong memorability. Kim (2014) suggested that destination attributes such as infrastructure, approachability, traditional culture, events, service quality, destination hospitality, and attachment to destination lead to MTE. Extending the work of Kim et al. (2012), Sthapit \& Coudounaris (2018) found that hedonism and meaningfulness augment travelers' memorability of the tour experience and subjective well-being. They further stated that novelty, local culture, knowledge, involvement, refreshment, togetherness, and creativity could also be part of tourists' subjective well-being. Several researchers have further conducted academic inquiries to examine the relevance of culinary and restaurant experience in the overall MTE.

In the recent study, Seyfi, Hall \& Rasoolimanesh (2020) explored the attributes of memorable cultural tourism experiences and advocated that authenticity, engagement, culinary attraction and quality of service are the important determinants. Another recent study conducted by Widjaja, Jokom, Kristanti, \& Wijaya (2020) discovered that culinary 
experience has a significant role in creating high-quality travelling experience and tourist satisfaction with the destination. Researchers explained that the unique food presentation, different style of service and dining ambience reflecting the local culture make the culinary experiences memorable. Interestingly, they also found that the quality of the dining place emerged as the main satisfier indicator of culinary experience satisfaction.

\section{2) MEMORABLE FOOD \& RESTAURANT EXPERIENCE}

A destination has to deliver the experience that the traveler searches for because it is a combination of physical, natural, socio-cultural, and artistic resources (Cracolici, Nijkamp \& Rietveld, 2008). Individuals travel for unique experiences, and traveling does not truly make logic if it is merely a repetition of the usual activities. Tourists perceive food as a delightful holiday activity (Henderson, 2009; Quan \& Wang, 2004). Consumption of authentic food in traditional restaurants connects tourists with destination's local geography, communities, their lifestyles, cultural, social and economic aspects, add value to a destination (Wijaya et al., 2013; Hendijani, 2016) and contributes to overall tourist experience (Björk \& Kauppinen-Räisänen, 2016). Several researchers found that food-related attributes contribute positively to seven dimensions of Kim's (2014) MTE scale. Food delicacies of a destination satisfy the novelty attribute of memorable experiences (Kivela \& Crotts, 2006). Authentic food in the traditional destination helps tourists to advance their familiarity with the destination and its culture resources (Tung \& Ritchie, 2011), refresh them (Tsai, 2016) and enhance the meaningfulness of the experiences (Mitchell and Hall, 2003). As many individuals travel for food, Kim et al., (2009), and Kim (2014) attested the fact that tourists' involvement with local food is increasing, and this involvement enhances their gastronomic experiences.

Tung and Ritchie (2011) and Chandralal and Valenzuela (2013) revealed that experiencing the traditional restaurants of a destination deepens the memorability of the travel experience. Comprehending the link between memorability and food experiences, 
Sthapit (2017) proposed a theoretical model of memorable food experience, which consists of local specialities and food attributes (taste), authenticity, novelty, togetherness, and social interaction, hospitality, servicescape, and food souvenirs. Stone et al. (2018) indicated that a single element of traveling does not often lead to a memorable experience. Type of food, food quality, the context, the companion(s), local, authentic, and novel attributes contribute to a memorable experience. Besides, a memorable destination is not needed for a memorable gastronomic experience. Kala (2020) and Kala \& Barthwal (2020) recommended that various food and restaurant attributes such as local food, food preparation \& presentation style, hygienic amenities, the appearance of service personnel, and local socio-cultural objects contribute to tourist satisfaction and memorable touristic experience. Researchers including Kivela \& Crotts (2006), Meng et al. (2008), Correia et al. (2008) verified that food quality is one of the significant components of the tourist experience. Several scholars incorporated the several characteristics of food quality such as taste, fresh and healthy ingredients (Alonso et al., 2013; Hendijani, 2016), healthy food options (Seo, Yun \& Kim, 2017), hygiene (Chao, 2010), variety (Chang et al., 2011; Stone et al. 2018), novel and genuine food (Sthapit, 2017). The usage of locally grown ingredients, traditional food preparation and presentation styles make the destination food more distinctive, therefore it is deliberated as an essential element in visitors' culinary experience (Namkung \& Jang, 2007; Karim \& Chi, 2010; Ryu, Lee \& Kim, 2012; Chi et al., 2013; Hendijani, 2016; Seo, Yun \& Kim, 2017). Piramanayagam et al (2020) advocated that the local food experiencescape have significant effects on tourists' memorable experiences. They found that Tourist expressed that experiencing the local food at local food joints makes their visit more memorable.

Since tourism involves travel outside the usual surroundings, attributes of restaurants (e.g., service quality, employees' aspects, and ambience), locations, and surroundings contributed to MTE. Service quality in the restaurant is found as the most significant driver of visitor satisfaction and experience (Liu \& Jang, 2009; Kim, Eves \& Scarles, 2009; Marinkovic et al., 2014). Chow et al. (2007) recognized three dimensions of service quality i.e., interaction, physical, outcome, and indicated their positive impact on guest satisfaction. During the 'moment-of-truth', appearance, traditional dressing, 
emotions, and professional abilities of restaurant staff promote social interaction and attachment with visitor and thus enrich visitor experience (Heung, Wong \& Qu, 2002; Liu \& Jang, 2009; Sthapit, 2017). Hendijani (2016) revealed that indigenous dressing style of staff in restaurants enhance guest satisfaction. Wu \& Liang (2009) acknowledged physical amenities, employees' skills and reliability, and meaningful interactions with guest as three significant attributes of the restaurant. Kim (2014) and Sthapit (2017) have also acknowledged the importance of "meaningful social interaction" between visitors and service staff to create memorable experiences.

Wu \& Liang (2009), Heung \& Gu (2012), and Ryu, Lee, \& Kim (2012) confirmed that facility aesthetics and ambience of the restaurant positively influence tourist satisfaction and experience. Mak, Lumbers, \& Eves (2012) attested the importance of the restaurant menu and pictographic demonstrations of cuisines in visitor satisfaction. Hendijani (2016) emphasized that showcasing of local cultural objects in restaurants represents the heritage of the destination and delivers an authentic experience. Kim, Eves \& Scarles (2009), Wu \& Liang (2009), Heung \& Gu (2012), and Marinkovic et al. (2014) supported that the atmosphere and restaurant location also add to visitors' satisfaction. Several researchers supported that consuming authentic foods in the scenic surroundings improve guest satisfaction and augment the memorable experience (Chang et al., 2011; Chi et al., 2013; Adongo et al., 2015; Hendijani, 2016; Tsai, 2016; Björk \& Kauppinen-Räisänen, 2016; Björk \& Kauppinen-Räisänen, 2017; Sthapit, 2017). Employing the Importance-Performance Analysis, Karamustafa \& Ülker (2020) pointed out that employee factors such as willingness to provide services, courtesy and interpersonal communication, and cleanliness are the most important attributes in restaurant satisfaction. MTE primarily considers a destination or visit altogether, but food \& restaurant attributes are the sources of many memories. This study attempts to determine the factors of memorable food and restaurant experience and model the interrelationships among them using interpretive structural modeling (ISM) in the mountainous destination.

\section{METHODOLOGY}




\section{1) THE STUDY AREA: UTTARAKHAND}

Situated in the northern part of India, Uttarakhand state shares an international boundary with Nepal and Tibet (China), and the national border with two Indian states Himachal Pradesh and Uttar Pradesh. Hindu pilgrimage shrines Badrinath and Kedarnath, six national parks, seven wildlife sanctuaries, two world heritage sites, historic temples, nature, wildlife, spiritual association, yoga, meditation, peaks, thick forest cover, valleys, glaciers, rivers, rich biodiversity are the strengths of this Himalayan state. The state has concentrated in tourism significantly for employment generation, development of rural areas, better standard of living, and revenue generation for the state. As per the statistics of the Indian Ministry of Tourism, 36.8 million tourists visited this mountainous state in the year 2018.

\section{2) THE CONTEXT OF USING ISM}

ISM is a useful analytical tool that simplifies ambiguous and inadequate psychological models and complex systems of multiple attributes into a visualized hierarchical framework employing qualitative methods like brainstorming meetings with industry practitioners (Thakkar, Kanda, \& Deshmukh, 2008). Since ISM ascertains relationships of dependent, driving, linkage, and autonomous variables, this work can pronounce a reliable base for measuring experiential value by establishing a hierarchical interpretive structure for memorable food and restaurant experience (MFRE). ISM approach relies on reviews of relevant studies, semi-structured interviews, subjective judgments of industry expert and brainstorming sessions to gather information, identify relevant variables, and establish relationships with them.

\section{3) APPLICATION OF ISM}

ISM starts with the conversion of a complex structure into numerous variables with the help of available literature and knowledge of experts. Then, a context-based pertinent linkage is developed among identified variables. Structural self-interaction 
matrix, transitivity, reachability matrix, level partition, and conical matrix are further steps to develop a model known as ISM.

\section{4) CRITICAL FACTORS IDENTIFICATION FOR MFRE}

Review of relevant past studies, interaction with tourism \& hospitality experts, and survey of tourists helped in identifying appropriate variables of MFRE. As a result, three lists (one list from each i.e., literature review, experts, and tourists) of MFRE variables were obtained. Then, these lists were given to another panel of experts (restaurateurs and tourism \& hospitality professors) to get the final list of MFRE variables. The participation of tourists, industry practitioners, and academicians in the procedure of identifying important MFRE variables offers more excellent reliability to outcomes. The detailed procedure of the literature review, experts' interaction, and tourists' survey are discussed below.

Review of Literature: Previous relevant studies on food and restaurant experience in the context of the hospitality industry in general and mountainous destination, in particular, was rigorously reviewed. Within the preview of selected databases (Scopus, EBSCO, Emerald, Elsevier, Taylor \& Francis and Sage), the researcher used various keywords such as tourists' food experience, restaurant service, restaurant experience, local food, gastronomic experience, culinary experience, and memorable tourist experience in authentic restaurants, to find important studies. Only the articles appearing in journals and published from 2005 to 2018 were considered in the review. The search resulted in 86 research documents. Fifteen conference papers and book chapters were excluded from the review process. Next, the abstracts of the selected articles were carefully reviewed. Based on abstract quality, article citations, the reputation of the journal and relevance to study objectives, 45 relevant articles, published in 24 different journals, were used in the literature review finally. These 45 finalized articles were distributed to six academicians to identify MFRE variables. Out of six academicians, two were full professors, and four were associate professors in tourism \& hospitality domain. All of them had more than ten years of academic and research experience. After two weeks, an interactive session with all six academicians 
was organized to finalize MFRE variables. The session lasts for two hours, and a consensus was reached on 18 MFRE variables.

Tourism \& Hospitality Experts: Tourism and hospitality experts were approached to participate in the study, and a schedule was arranged for the interaction. On the scheduled date, a 60 minutes session was conducted with six tourism and hospitality experts (one tour operator, three fine-dining restaurateurs, and two senior managers of mid-scale hotels). Out of six, four tourism \& hospitality experts were from the mountainous destinations of Uttarakhand, while two experts were from nonmountainous destinations of Uttarakhand. Professional qualification and more than five years of industry experience were criteria to be included as experts in this study. All experts interacted, shared their viewpoints, and suggested MFRE variables. After deliberation, a list of 15 MFRE variables was finalized.

Tourists: Tourists were told to describe their experiences with food and restaurants. Two criteria were used to select the respondents. First, respondents should have enjoyed their meals in restaurants, located in the mountainous destinations of Uttarakhand, India. Second, they must have visited these destinations within the last six months. Local travelers were excluded from the sample. Eighty respondents with age ranged from 21 to 62 years were selected randomly from the database of hotels run and operated by Garhwal Mandal Vikas Nigam - a state-owned Tourism Corporation. During sample selection, the researcher tried to incorporate the opinions of tourists of different socio-demographic profiles to assess varied observations, viewpoints, and understanding of memorable culinary experience. These selected tourists were approached over phone or email. Thirty-six tourists participated voluntarily, and their views were kept confidential. On inquiring about the purpose of visit, 18 participants visited the destinations for a religious purpose, 10 participants visited for adventurous/recreational purposes, and four visited for particular interest (photography $\&$ wildlife). The remaining four tourists did not provide any information. There were 25 male and 11 female visitors in the sample. An online session of 90 minutes was arranged to collect the responses of tourists. In order to bring out the actual feelings of respondents, researchers gave 10 minutes briefing about the objectives of the study. 
Each participant was given two minutes to describe his or her touristic experiences in the mountainous destinations of Uttarakhand. Mirroring the approach of Brakus et al. (2009), and Khan \& Rehman (2016), the researcher then instructed respondents to write their experiences on a paper and essential attributes of food \& restaurant experiences in mountainous and semi-urban destinations. After the session, they were instructed to send photos of their responses via email or WhatsApp. The content analysis of the observations shown that tourists highlighted various attributes of food and restaurant experiences, indicating the memorable gastronomy experience played a determinant role in overall tourists' satisfaction. Based on tourist responses, $20 \mathrm{MFRE}$ variables were finalized.

These final lists thus prepared were given to a group of six experts (one tourism professor, one marketing professor, two managers of fine dining restaurants, and two tourists) to deliberate on MFRE variables through a discussion and finalize them. None of the experts was repeated from the previous stages. Except for tourists, experts had more than five years of professional experience in their domain. Surprisingly, eight items were common in these three lists. Experts also combined some similar attributes into one comprehensive and appropriate variable. The researcher was present during the session and noted down the unanimously agreed upon variables for the study. The discussion lasted 45 minutes and finalized 14 variables of MFRE (see Table 1). 


\begin{tabular}{|c|c|c|c|}
\hline ID & Variable & Description & Relevant Literature \\
\hline RL & $\begin{array}{l}\text { Restaurant } \\
\text { Location }\end{array}$ & $\begin{array}{l}\text { The convenience, hassle-free and attractive } \\
\text { site of the restaurant. }\end{array}$ & $\begin{array}{l}\text { Meng et al. (2008), Alonso et al. (2013), Stone } \\
\text { et al. (2018) }\end{array}$ \\
\hline $\mathrm{HC}$ & $\begin{array}{l}\text { Hygiene \& } \\
\text { Cleanliness }\end{array}$ & $\begin{array}{l}\text { Ensuring every area of a restaurant is clean, } \\
\text { including washroom, kitchen, furniture, } \\
\text { crockery, and cutlery. }\end{array}$ & $\begin{array}{l}\text { Correia et al. (2008), Henderson (2009), Ryu } \\
\text { et al. (2012), Seo et al. (2017), Hendijani } \\
\text { (2016), Karamustafa \& Ülker (2020) }\end{array}$ \\
\hline D & Decoration & $\begin{array}{l}\text { It comprises light, color, presentation of } \\
\text { furniture, wall decorations, crowding, } \\
\text { temperature, menu design and internal } \\
\text { appearance of the restaurant. }\end{array}$ & $\begin{array}{l}\text { Heung et al. (2002), Correia et al. (2008), } \\
\text { Meng et al. (2008), Ryu et al. (2012) }\end{array}$ \\
\hline RAM & $\begin{array}{l}\text { Restaurant } \\
\text { Atmosphere }\end{array}$ & $\begin{array}{l}\text { It includes the sense of connectedness, } \\
\text { delightful, a lively feel through music, and } \\
\text { relaxed spatial organization for visitors. }\end{array}$ & $\begin{array}{l}\text { Correia et al. (2008), Ryu et al. (2012), Alonso } \\
\text { et al (2013), Björk \& Kauppinen-Räisänen, } \\
(2016)\end{array}$ \\
\hline PEE & $\begin{array}{l}\text { Physical } \\
\text { Environment } \\
\text { Experience }\end{array}$ & $\begin{array}{l}\text { This variable motivates guests to patronize the } \\
\text { restaurant. It includes attractive design, } \\
\text { architecture, modernization and outer } \\
\text { ambience of the restaurant. }\end{array}$ & $\begin{array}{l}\text { Correia et al. (2008), Kim et al. (2009), Ryu et } \\
\text { al. (2012), Khan \& Rehman (2016), Sthapit } \\
(2017)\end{array}$ \\
\hline SSCO & $\begin{array}{l}\text { Showcasing } \\
\text { Socio-Cultural } \\
\text { Objects }\end{array}$ & $\begin{array}{l}\text { Display of local, indigenous and destination- } \\
\text { specific souvenirs in the restaurant in order to } \\
\text { make visitors more attached with destination } \\
\text { and create a meaningful experience. }\end{array}$ & $\begin{array}{l}\text { Kivela \& Crotts (2006), Correia et al. (2008), } \\
\text { Sims (2009), Ryu et al. (2012), Alonso et al } \\
\text { (2013), Chi et al. (2013), Kala (2020), Widjaja } \\
\text { et al (2020) }\end{array}$ \\
\hline TFP & $\begin{array}{l}\text { Traditional Food } \\
\text { Preparation }\end{array}$ & $\begin{array}{l}\text { Conventional food preparation styles using } \\
\text { traditional equipment to preserve the flavour, } \\
\text { originality, and authenticity of cuisines. }\end{array}$ & $\begin{array}{l}\text { Karim \& Chi (2010), Chang et al. (2011), Chi et } \\
\text { al. (2013), Hendijani (2016), Björk \& } \\
\text { Kauppinen-Räisänen, (2016), Seo et al. (2017) }\end{array}$ \\
\hline ALF & $\begin{array}{l}\text { Authentic Local } \\
\text { Food }\end{array}$ & $\begin{array}{l}\text { Cuisine that is prepared with local ingredients, } \\
\text { cooked in the traditional method, and } \\
\text { consumed by the locals for several }\end{array}$ & $\begin{array}{l}\text { Correia et al. (2008), Henderson (2009), Sims } \\
\text { (2009), Karim \& Chi (2010), Chang et al. } \\
\text { (2011), Björk \& Kauppinen-Räisänen, (2016), }\end{array}$ \\
\hline
\end{tabular}


generations

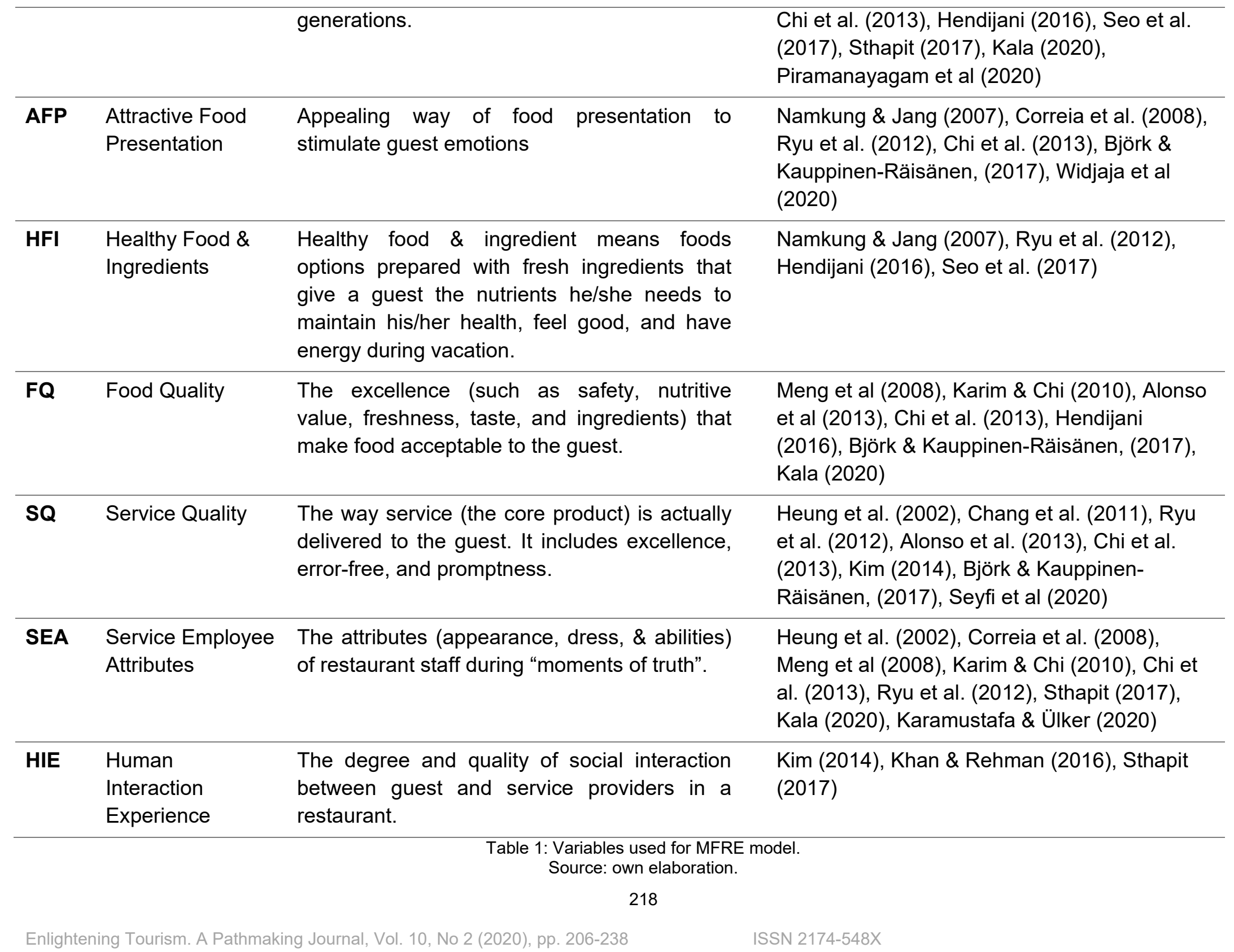




\section{ANALYSIS}

\section{1) STRUCTURAL SELF-INTERACTION MATRIX (SSIM)}

The pairwise examination among the 14 selected MFRE factors and one MFRE itself was performed. The experts, contacted in the previous stage, were also consulted to develop a contextual "leads to" relationship among the identified variables. This created a contextually valid relationship-based diagram. As adopted by previous researchers, including Kannan, Pokharel, \& Kumar (2009), and Khan \& Rehman (2016), the diagram indicating the relevant relationships among variables was shared among the experts to seek feedback for further modifications. Four symbols were used to describe the relationships between a pair of variables ( $i$ and $j)$. Table 2 indicates symbols and their explanations.

\begin{tabular}{c|l}
\hline Symbols & Descriptions \\
$\mathbf{V}$ & Variable $\mathrm{i}$ will lead to achieve variable $\mathrm{j}$ \\
$\mathbf{A}$ & Variable $\mathrm{j}$ will lead to achieve variable $\mathrm{i}$ \\
$\mathbf{X}$ & Variable $\mathrm{i}$ and $\mathrm{j}$ will lead to achieve each other \\
$\mathbf{0}$ & There is no connection between variable $\mathrm{i}$ and $\mathrm{j}$ \\
\hline \multicolumn{2}{c}{ Table 2: Symbols and their explanations in SSIM. } \\
Source: own elaboration.
\end{tabular}

\begin{tabular}{|c|c|c|c|c|c|c|c|c|c|c|c|c|c|c|}
\hline & MFRE & HIE & SEA & $\mathbf{S Q}$ & $\mathbf{F Q}$ & HFI & AFP & ALF & TFP & SSCO & PEE & RAM & D & HC \\
\hline $\mathbf{R L}$ & V & $\mathrm{O}$ & 0 & $\mathrm{O}$ & 0 & $\mathrm{O}$ & 0 & $\mathrm{O}$ & $\mathrm{O}$ & 0 & V & V & 0 & V \\
\hline HC & V & $\mathrm{O}$ & A & V & X & A & $\mathrm{O}$ & 0 & 0 & 0 & V & $X$ & 0 & \\
\hline D & V & $\mathrm{O}$ & $\mathrm{O}$ & 0 & $\mathrm{O}$ & 0 & $X$ & 0 & 0 & A & V & V & & \\
\hline RAM & V & A & A & V & V & O & $X$ & A & 0 & A & V & & & \\
\hline PEE & V & O & A & V & 0 & O & A & O & 0 & A & & & & \\
\hline ssco & V & O & 0 & 0 & $\mathrm{O}$ & O & $X$ & V & V & & & & & \\
\hline TFP & V & $x$ & A & X & V & A & $x$ & V & & & & & & \\
\hline ALF & V & $X$ & $X$ & V & V & A & $X$ & & & & & & & \\
\hline AFP & V & $X$ & $X$ & V & V & A & & & & & & & & \\
\hline HFI & V & $X$ & 0 & O & V & & & & & & & & & \\
\hline $\mathbf{F Q}$ & V & A & A & A & & & & & & & & & & \\
\hline $\mathbf{S Q}$ & V & A & A & & & & & & & & & & & \\
\hline SEA & V & V & & & & & & & & & & & & \\
\hline HIE & V & & & & & & & & & & & & & \\
\hline MFRE & & & & & & & & & & & & & & \\
\hline
\end{tabular}

Table 3: Structural Self-Interaction Matrix. Source: own elaboration. 
Table 3 reveals that hygiene \& cleanliness $(\mathrm{HC})$ leads to memorable food \& restaurant experience (MFRE), so the symbol $V$ was assigned to this relationship. For service quality (SQ) and service employee attributes (SEA), variable SQ is preceded by variable SEA; therefore the relationship is given the $A$ notation. Since healthy food \& ingredients ( $\mathrm{HFI}$ ) is not related to decoration (D), this relationship is assigned symbol $\mathrm{O}$.

\section{2) REACHABILITY MATRIX (RM)}

In this stage, the transformation of SSIM into reachability matrix is taken place by translating notations into binary numbers (ones or zeros) as per the instruction indicated in Table 4. Table 5 presents the initial reachability matrix.

\begin{tabular}{cl} 
SSIM & Initial Reachability Matrix \\
If symbol in the cell $(i, j)$ is: & \\
V & 1 is entered to $(i, j)$ and 0 is entered to $(j, i)$ \\
A & 0 is entered to $(i, j)$ and 1 is entered to $(j, i)$ \\
$X$ & 1 is entered to both $(i, j)$ and $(j, i)$ \\
O & 0 is entered to both $(i, j)$ and $(j, i)$ \\
\hline
\end{tabular}

Table 4: The guidelines for transforming SSIM into initial Reachability Matrix.

Source: own elaboration.

\begin{tabular}{lcccccccccccccccc} 
& MFRE & RL & HC & D & RAM & PEE SSCO TFP & ALF & AFP & HFI & FQ & SQ & SEA & HIE \\
\hline RL & 1 & 1 & 1 & 0 & 1 & 0 & 0 & 0 & 0 & 0 & 0 & 0 & 0 & 0 & 0 \\
HC & 1 & 0 & 1 & 0 & 1 & 1 & 0 & 0 & 0 & 0 & 0 & 1 & 1 & 0 & 0 \\
D & 1 & 0 & 0 & 1 & 1 & 1 & 0 & 0 & 0 & 1 & 0 & 0 & 0 & 0 & 0 \\
RAM & 1 & 0 & 1 & 0 & 1 & 1 & 0 & 0 & 0 & 1 & 0 & 1 & 1 & 0 & 0 \\
PEE & 1 & 0 & 0 & 0 & 0 & 1 & 0 & 0 & 0 & 0 & 0 & 0 & 1 & 0 & 0 \\
SSCO & 1 & 0 & 0 & 1 & 1 & 1 & 1 & 1 & 1 & 1 & 0 & 0 & 0 & 0 & 0 \\
TFP & 1 & 0 & 0 & 0 & 0 & 0 & 0 & 1 & 1 & 1 & 0 & 1 & 1 & 0 & 1 \\
ALF & 1 & 0 & 0 & 0 & 1 & 0 & 0 & 0 & 1 & 1 & 0 & 1 & 1 & 1 & 1 \\
AFP & 1 & 0 & 0 & 1 & 1 & 1 & 1 & 1 & 1 & 1 & 0 & 1 & 1 & 1 & 1 \\
HFI & 1 & 0 & 1 & 0 & 0 & 0 & 0 & 1 & 1 & 1 & 1 & 1 & 0 & 0 & 1 \\
FQ & 1 & 0 & 1 & 0 & 0 & 0 & 0 & 0 & 0 & 0 & 0 & 1 & 0 & 0 & 0 \\
SQ & 1 & 0 & 0 & 0 & 0 & 0 & 0 & 1 & 0 & 0 & 0 & 1 & 1 & 0 & 0
\end{tabular}




\begin{tabular}{llllllllllllllll} 
SEA & 1 & 0 & 1 & 0 & 1 & 1 & 0 & 1 & 1 & 1 & 0 & 1 & 1 & 1 & 1 \\
HIE & 1 & 0 & 0 & 0 & 1 & 0 & 0 & 1 & 1 & 1 & 1 & 1 & 1 & 0 & 1 \\
MFRE & 1 & 0 & 0 & 0 & 0 & 0 & 0 & 0 & 0 & 0 & 0 & 0 & 0 & 0 & 0 \\
\hline \multicolumn{7}{c}{ Table 5: Initial Reachability Matrix. }
\end{tabular}
Source: own elaboration.

Substitution of $\mathrm{V}, \mathrm{X}, \mathrm{A}$, and $\mathrm{O}$ by 1 and 0 gives a binary matrix, which has been checked for transitivity. Transitivity means if variable $A$ contributes to $B$ and variable $B$ contributes to $C$, then $A$ is necessarily contributing to $C$. The final reachability matrix then comprises of entries from pair-wise assessments. The final reachability matrix is attained by integrating transitivities (Table 6). In the final RM, horizontal values show driving power and vertical values represent the dependence power of variables. For example, the driving and dependence power of variable decoration (D) are 5 and 8, respectively.

\begin{tabular}{|c|c|c|c|c|c|c|c|c|c|c|c|c|c|c|c|c|c|}
\hline & MFRE & $\mathbf{R L}$ & HC & D & RAM & PEE & Sco & TFP & ALF & AFP & HFI & $\mathbf{F Q}$ & SQ & SEA & HIE & $\begin{array}{l}\text { Driver } \\
\text { Power }\end{array}$ & Ranks \\
\hline $\mathbf{R L}$ & 1 & 1 & 1 & 0 & 1 & 1 & 0 & 0 & 0 & 1 & 0 & 1 & 1 & 0 & 0 & 8 & $\mathrm{~V}$ \\
\hline $\mathrm{HC}$ & 1 & 0 & 1 & 0 & 1 & 1 & 0 & 0 & 0 & 1 & 0 & 1 & 1 & 0 & 0 & 7 & VI \\
\hline D & 1 & 0 & 0 & 1 & 1 & 1 & 0 & 0 & 0 & 1 & 0 & 0 & 0 & 0 & 0 & 5 & VII \\
\hline RAM & 1 & 0 & 1 & 1 & 1 & 1 & 0 & 0 & 0 & 1 & 0 & 1 & 1 & 0 & 0 & 8 & V \\
\hline PEE & 1 & 0 & 0 & 0 & 0 & 1 & 0 & 0 & 0 & 0 & 0 & 0 & 1 & 0 & 0 & 3 & VIII \\
\hline ssco & 1 & 0 & 0 & 1 & 1 & 1 & 1 & 1 & 1 & 1 & 0 & 0 & 1 & 0 & 0 & 9 & IV \\
\hline TFP & 1 & 0 & 0 & 0 & 0 & 0 & 0 & 1 & 1 & 1 & 0 & 1 & 1 & 1 & 1 & 8 & V \\
\hline ALF & 1 & 0 & 0 & 0 & 1 & 0 & 1 & 1 & 1 & 1 & 0 & 1 & 1 & 1 & 1 & 10 & III \\
\hline AFP & 1 & 0 & 1 & 1 & 1 & 1 & 1 & 1 & 1 & 1 & 0 & 1 & 1 & 1 & 1 & 13 & I \\
\hline HFI & 1 & 0 & 1 & 0 & 1 & 1 & 0 & 1 & 1 & 1 & 1 & 1 & 0 & 0 & 1 & 10 & III \\
\hline $\mathbf{F Q}$ & 1 & 0 & 1 & 1 & 1 & 0 & 0 & 1 & 1 & 1 & 0 & 1 & 0 & 1 & 1 & 10 & III \\
\hline SQ & 1 & 0 & 0 & 1 & 1 & 0 & 0 & 1 & 1 & 0 & 0 & 1 & 1 & 1 & 1 & 9 & IV \\
\hline SEA & 1 & 0 & 1 & 1 & 1 & 1 & 0 & 1 & 1 & 1 & 0 & 1 & 1 & 1 & 1 & 12 & II \\
\hline HIE & 1 & 0 & 0 & 1 & 1 & 0 & 0 & 1 & 1 & 1 & 1 & 1 & 1 & 0 & 1 & 10 & III \\
\hline MFRE & 1 & 0 & 0 & 0 & 0 & 0 & 0 & 0 & 0 & 0 & 0 & 0 & 0 & 0 & 0 & 1 & IX \\
\hline $\begin{array}{l}\text { Depen } \\
\text { dence }\end{array}$ & 15 & 1 & 7 & 8 & 12 & 9 & 3 & 9 & 9 & 12 & 2 & 11 & 11 & 6 & 8 & & \\
\hline Ranks & 1 & $X$ & VI & V & II & IV & VIII & IV & IV & II & IX & III & III & VII & V & & \\
\hline
\end{tabular}




\section{3) LEVEL PARTITIONS AND CONICAL MATRIX}

The reachability and an antecedent set for each variable can be extracted from the final RM. The reachability set contains the variable itself and other variables to which it may contribute to attaining, while the antecedent set comprises the variable itself and other variables that may help to achieve this variable. Variables that are recorded in both reachability and antecedent sets are placed in the intersection set. The top position in ISM is attained by the variable whose reachability and intersection sets become the same. In table 7, it can be seen that MFRE is the top-level variable (Level I). The process of further iterations takes place until the level of each variable is identified in the formation of the ISM structure. Table $7 \& 8$ show the level partitions.

\begin{tabular}{|c|c|c|c|c|}
\hline Variable & Reachability Set & Antecedent Set & Intersection Set & Level \\
\hline $\mathrm{RL}$ & $\begin{array}{l}\text { RL, HC, RAM, PEE, AFP, FQ, SQ, } \\
\text { MFRE }\end{array}$ & $\mathrm{RL}$ & $\mathrm{RL}$ & \\
\hline $\mathrm{HC}$ & $\begin{array}{l}\text { HC, RAM, PEE, AFP, FQ, SQ, } \\
\text { MFRE }\end{array}$ & RL, HC, RAM, AFP, HFI, FQ, SEA & HC, RAM, AFP, FQ & \\
\hline D & $\begin{array}{l}\text { HC, RAM, PEE, AFP, FQ, SQ, } \\
\text { MFRE }\end{array}$ & $\begin{array}{l}\text { D, RAM, SSCO, AFP, FQ, SQ, } \\
\text { SEA, HIE }\end{array}$ & D, RAM, AFP & \\
\hline RAM & $\begin{array}{l}\text { HC, D, RAM, PEE, AFP, FQ, SQ, } \\
\text { MFRE }\end{array}$ & $\begin{array}{l}\text { RL, HC, D, RAM, SSCO, ALF, } \\
\text { AFP, HFI, FQ, SQ, SEA, HIE }\end{array}$ & $\begin{array}{l}\text { HC, D, RAM, AFP, } \\
F Q, S Q\end{array}$ & \\
\hline PEE & PEE, SQ, MFRE & $\begin{array}{l}\text { RL, HC, D, RAM, PEE, SSCO, } \\
\text { AFP, HFI, SEA }\end{array}$ & PEE & \\
\hline SSCO & $\begin{array}{l}\text { D, RAM, PEE, SSCO, TFP, ALF, } \\
\text { AFP, SQ, MFRE }\end{array}$ & SSCO, ALF, AFP & SSCO & \\
\hline TFP & $\begin{array}{l}\text { TFP, ALF, AFP, FQ, SQ, SEA, } \\
\text { HIE, MFRE }\end{array}$ & $\begin{array}{l}\text { SSCO, TFP, ALF, AFP, HFI, } \\
\text { FQ,SQ,SEA, HIE }\end{array}$ & $\begin{array}{l}\text { TFP, ALF, AFP, FQ, } \\
\text { SQ, SEA, HIE }\end{array}$ & \\
\hline ALF & $\begin{array}{l}\text { RAM, SSCO, TFP, ALF, AFP, FQ, } \\
\text { SQ, SEA, HIE, MFRE }\end{array}$ & $\begin{array}{l}\text { SSCO, TFP, ALF, AFP, HFI, FQ, } \\
\text { SQ, SEA, HIE }\end{array}$ & $\begin{array}{l}\text { SSCO, TFP, ALF, } \\
\text { AFP, FQ, SQ, SEA, } \\
\text { HIE }\end{array}$ & \\
\hline AFP & $\begin{array}{l}\text { HC, D, RAM, PEE, SSCO, TFP, } \\
\text { ALF, AFP, FQ, SQ, SEA, HIE, } \\
\text { MFRE }\end{array}$ & $\begin{array}{l}\text { RL, HC, D, RAM, SSCO,, TFP, } \\
\text { ALF, AFP, HFI, FQ, SEA, HIE }\end{array}$ & $\begin{array}{l}\text { HC, D, RAM, } \\
\text { SSCO, TFP, ALF, } \\
\text { AFP, FQ, SEA, HIE }\end{array}$ & \\
\hline $\mathrm{HFI}$ & $\begin{array}{l}\text { HC, RAM, PEE, TFP, ALF, AFP, } \\
\text { HFI, FQ,HIE, MFRE }\end{array}$ & $\mathrm{HFI}, \mathrm{HIE}$ & $\mathrm{HFI}, \mathrm{HIE}$ & \\
\hline $\mathrm{FQ}$ & $\begin{array}{l}\text { HC, D, RAM, TFP, ALF, FQ, SQ, } \\
\text { SEA, HIE, MFRE }\end{array}$ & $\begin{array}{l}\text { RL, HC, RAM, TFP, ALF, AFO, } \\
\text { HFI, FQ, SQ, SEA, HIE }\end{array}$ & $\begin{array}{l}\text { HC, RAM, TFP, } \\
\text { ALF, FQ, SQ, SEA, } \\
\text { HIE }\end{array}$ & \\
\hline$S Q$ & $\begin{array}{l}\text { D, RAM, TFP, ALF, FQ, SQ, SEA, } \\
\text { HIE, MFRE }\end{array}$ & $\begin{array}{l}\text { RL, HC, RAM, PEE, SSCO, TFP, } \\
\text { ALF, AFP, SQ, SEA, HIE }\end{array}$ & $\begin{array}{l}\text { RAM, TFP, ALF, } \\
\text { FQ, SQ, SEA, HIE }\end{array}$ & \\
\hline SEA & $\begin{array}{l}\text { HC, D, RAM, PEE, TFP, ALF, } \\
\text { AFP, FQ, SQ, SEA, HIE, MFRE }\end{array}$ & TFP, ALF, AFP, FQ, SQ, SEA, HIE & $\begin{array}{l}\text { TFP, ALF, AFP, FQ, } \\
\text { SQ, SEA }\end{array}$ & \\
\hline HIE & $\begin{array}{l}\text { D, RAM, TFP, ALF, AFP, HFI, FQ, } \\
\text { SQ, HIE, MFRE }\end{array}$ & $\begin{array}{l}\text { TFP, ALF, AFP, HFI, FQ, SQ, } \\
\text { SEA, HIE }\end{array}$ & $\begin{array}{l}\text { TFP, ALF, AFP, } \\
\text { HFI, FQ. SQ. HIE }\end{array}$ & \\
\hline
\end{tabular}




\begin{tabular}{|l|l|l|l|l|}
\hline MFRE & MFRE & $\begin{array}{l}\text { RL, HC, D, RAM, PEE, SSCO, } \\
\text { TFP, ALF, AFP, HFI, FQ, SQ, } \\
\text { SEA, HIE, MFRE }\end{array}$ & MFRE
\end{tabular} \mid

Table 7: Level partitions for research factors. Iteration 1.

Source: own elaboration.

\begin{tabular}{|c|c|c|c|c|}
\hline Variable & Reachability Set & Antecedent Set & Intersection Set & Level \\
\hline $\mathrm{RL}$ & RL, HC, RAM, PEE, AFP & $\mathrm{RL}$ & $\mathrm{RL}$ & VI \\
\hline $\mathrm{HC}$ & HC, RAM, PEE, AFP, FQ & $\begin{array}{l}\text { RL, HC, RAM, AFP, HFI, FQ, } \\
\text { SEA }\end{array}$ & HC, RAM, AFP, FQ & III \\
\hline D & HC, RAM, PEE, AFP, SQ & $\begin{array}{l}\text { D, RAM, SSCO, AFP, FQ, SQ, } \\
\text { SEA, HIE }\end{array}$ & $\mathrm{D}, \mathrm{RAM}, \mathrm{AFP}$ & VI \\
\hline RAM & HC, RAM, PEE, AFP, FQ & $\begin{array}{l}\text { RL, HC, D, RAM, SSCO, ALF, } \\
\text { AFP, HFI, FQ, SQ, SEA, HIE }\end{array}$ & $\begin{array}{l}\text { HC, D, RAM, AFP, FQ, } \\
\text { SQ }\end{array}$ & III \\
\hline PEE & PEE & $\begin{array}{l}\text { RL, HC, D, RAM, PEE, SSCO, } \\
\text { AFP, HFI, SEA }\end{array}$ & PEE & II \\
\hline SSCO & RAM, PEE, TFP, ALF, AFP & SSCO, ALF, AFP & SSCO & $\mathrm{V}$ \\
\hline TFP & TFP, ALF, AFP, FQ & $\begin{array}{l}\text { SSCO, TFP, ALF, AFP, HFI, } \\
\text { FQ,SQ,SEA, HIE }\end{array}$ & $\begin{array}{l}\text { TFP, ALF, AFP, FQ, } \\
\text { SQ, SEA, HIE }\end{array}$ & III \\
\hline ALF & RAM, TFP, ALF, AFP, FQ & $\begin{array}{l}\text { SSCO, TFP, ALF, AFP, HFI, } \\
\text { FQ, SQ, SEA, HIE }\end{array}$ & $\begin{array}{l}\text { SSCO, TFP, ALF, AFP, } \\
\text { FQ, SQ, SEA, HIE }\end{array}$ & III \\
\hline AFP & PEE, AFP, FQ & $\begin{array}{l}\text { RL, HC, D, RAM, SSCO, , TFP, } \\
\text { ALF, AFP, HFI, FQ, SEA, HIE }\end{array}$ & $\begin{array}{l}\text { HC, D, RAM, SSCO, } \\
\text { TFP, ALF, AFP, FQ, } \\
\text { SEA, HIE }\end{array}$ & II \\
\hline $\mathrm{HFI}$ & $\mathrm{HC}, \mathrm{TFP}, \mathrm{ALF}, \mathrm{AFP}, \mathrm{FQ}$ & HFI, HIE & $\mathrm{HFI}, \mathrm{HIE}$ & IV \\
\hline $\mathrm{FQ}$ & $\mathrm{FQ}$ & $\begin{array}{l}\text { RL, HC, RAM, TFP, ALF, AFO, } \\
\text { HFI, FQ, SQ, SEA, HIE }\end{array}$ & $\begin{array}{l}\text { HC, RAM, TFP, ALF, } \\
\text { FQ, SQ, SEA, HIE }\end{array}$ & II \\
\hline SQ & RAM, TFP, ALF, FQ, SQ & $\begin{array}{l}\text { RL, HC, RAM, PEE, SSCO, } \\
\text { TFP, ALF, AFP, SQ, SEA, HIE }\end{array}$ & $\begin{array}{l}\text { RAM, TFP, ALF, FQ, } \\
\text { SQ, SEA, HIE }\end{array}$ & IV \\
\hline SEA & $\begin{array}{l}\text { HC, RAM, PEE, TFP, ALF, } \\
\text { AFP, FQ, SQ, SEA, HIE }\end{array}$ & $\begin{array}{l}\text { TFP, ALF, AFP, FQ, SQ, SEA, } \\
\text { HIE }\end{array}$ & $\begin{array}{l}\text { TFP, ALF, AFP, FQ, } \\
\text { SQ, SEA }\end{array}$ & $\mathrm{VI}$ \\
\hline HIE & $\begin{array}{l}\text { RAM, ALF, AFP, FQ, SQ, } \\
\text { HIE }\end{array}$ & $\begin{array}{l}\text { TFP, ALF, AFP, HFI, FQ, SQ, } \\
\text { SEA, HIE }\end{array}$ & $\begin{array}{l}\text { TFP, ALF, AFP, HFI, } \\
\text { FQ. SQ. HIE }\end{array}$ & $\mathrm{V}$ \\
\hline
\end{tabular}

Table 8: Level partitions for research factors (Iteration 2-6).

Source: own elaboration.

\section{RESULT}

\section{1) ISM MODEL DEVELOPMENT}

In order to form the ISM framework better understandable to restaurateurs, tourism service providers, tourism planners, and other concerned stakeholders, a diagram was 
prepared based on level partitions. In Figure 1, restaurant location (RL), decoration (D), and service employee attribute (SEA) occupy the foundation position in the model, indicating their significance in providing greater MFRE. A soothing RL helps in enticing guests. Decoration in the restaurant creates a favorable impression on visitors. Service employee attributes develop a sense of better and efficient services and attention to their needs. Attractive decorations and professional attributes of restaurant employees develop social interaction between guests and staff. Service employee attribute also contributes to delivering efficient and timely services and make guests happier by providing meaningful interactions with every visitor. Restaurant location and traditional way of decoration provide an opportunity to learn about local geography, host communities, their lifestyles, cultural, social, and economic aspects of the destination. A positive human interaction assists in delivering efficient and error-free services to guests. HIE variable also helps in communicating about the healthy food offerings of the destination and usages of quality ingredients, which are grown locally and available to the local geographical region only. These efficient and timely services are more likely to contribute to the attractiveness and comfortable atmosphere of the restaurant. Adequate service quality and healthy food \& ingredient lead to increased hygiene and cleanliness of the restaurant. Healthy food \& ingredients and displaying socio-cultural objects in the restaurant result in experiencing the traditional food preparation and authentic cooking methods of the region.

All these variables, namely, socio-cultural object display, service quality, healthy food \& ingredient, and traditional food preparation methods, ultimately result in the authentic local food offerings. Several pieces of research have supported that many tourists visit destination for seeking novel experiences and authentic local food and specialities are the essential components of their overall destination satisfaction (Correia, et al., 2008; Henderson, 2009; Sims, 2009; Karim \& Chi, 2010; Chang et al., 2011; Chi et al., 2013; Hendijani, 2016; Björk \& Kauppinen-Räisänen, 2017; Seo et al., 2017; Sthapit, 2017). ALF, TFP, HC, and RAM lead to another level of variables, such as authentic food presentation, food quality, and physical environment experience. Offering authentic local healthy food using traditional methods of food preparation and 
locally grown ingredients in the surroundings of the socio-cultural heritage of the destination increases the quality of foods. Authentic local food, exotic restaurant atmosphere, and attractive architectural restaurant assist in the attractive presentation of original food offerings. The exotic atmosphere leads to favorable physical environment experience. Finally, the proper management of these variables would further lead to MFRE.

Succinctly, it can be stated that selecting the best restaurant location, attractive decoration, and service employee attributes such as communication, attitude, appearance, helpful, and welcome gestures would form the basis for MFRE. These elements must be in accord with other elements namely, SSCO, HIE, HFI, SQ, ALF, TFP, HC, and RAM, that would enable delightful AFP, FQ, and PEE, which consequently would contribute to MFRE. 


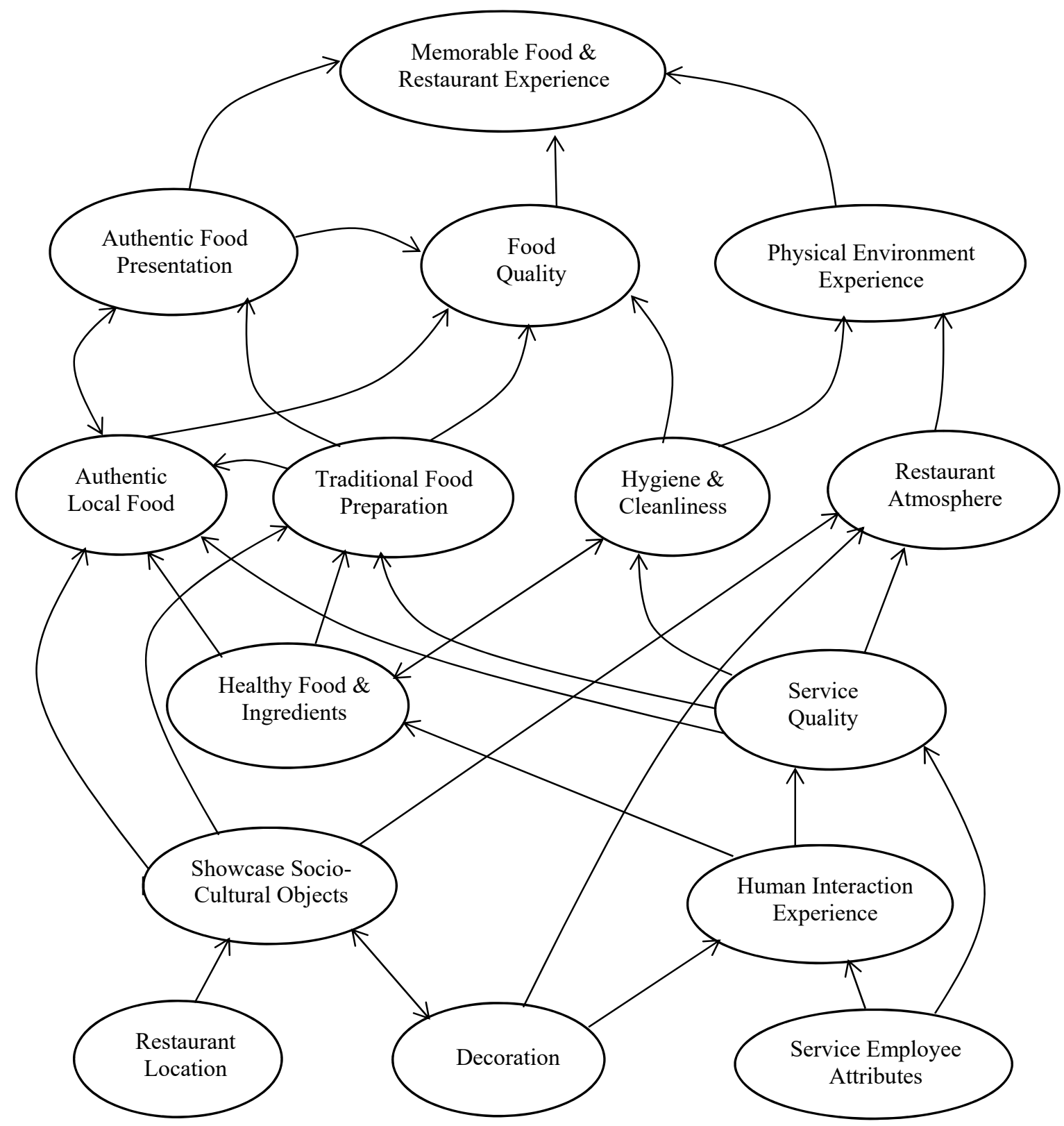

Figure 1: Interpretive structural modeling for MFRE.

Source: own elaboration.

\section{2) MICMAC ANALYSIS}

MICMAC analysis (Matrix Impact Cross-Reference Multiplication Applied to a Classification) was applied to examine the drive and dependence influence of identified 
variables of MFRE. For example, Table 6 shows that HFI variable retains the driving power of 10 and dependence of two. Therefore, HFI affects ten variables and rests on two variables. MICMAC is a depiction of factors in four segments - Independent, Linkage, Autonomous, and Dependent (Figure 2).

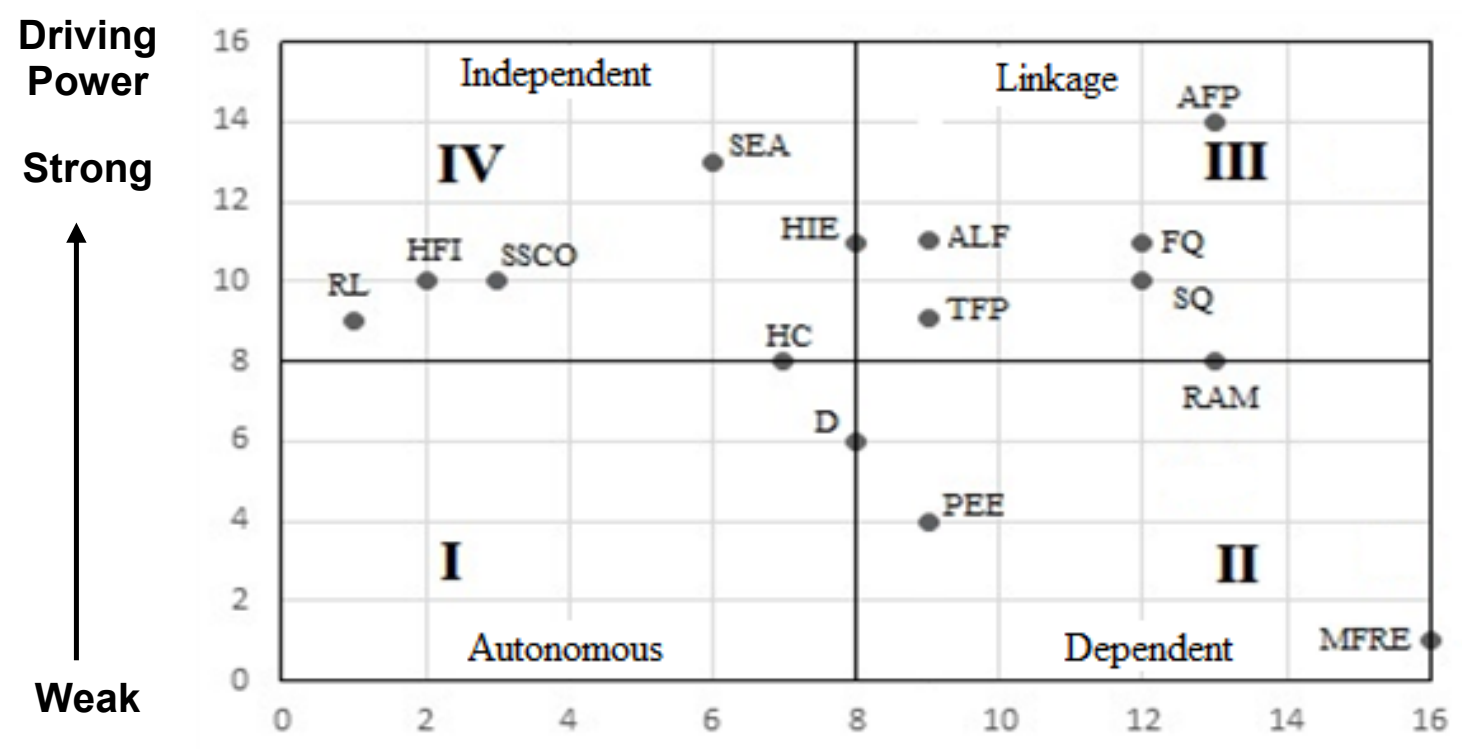

Weak

Strong Dependence

Figure 2. MICMAC analysis.

Source: own elaboration.

Variables of autonomous segment possess both weak drive power and dependence power. No variable was found in the autonomous segment. This signifies that all the identified variables are connected to MFRE and there is no disassociated variable. The second segment includes dependent variables that possess weak driving power but strong dependence power. The third segment comprises variables with strong driving and dependence power. These are termed as linkage variables. The general nature of these variables is unstable. The fourth segment contains the independent variables that possess strong driving power but weak dependence power. AFP, ALF, TFP, FQ, SQ, and RAM act as links between dependent and independent variables. An alteration in these variables can influence other variables. Variables such as PEE, D, and MFRE are dependent variables that are significantly reliance on RL, HFI, SSCO, HIE, SEA, and HC variables, which are bunched up as independent 
variables. These independent variables are significant as they show higher driving power toward MFRE.

\section{DISCUSSION}

Food and restaurant attribute not simply act as physiological requirements but constitutes an important aspect of the travel experience. Employing the ISM approach, this study attempted to establish the interrelationship among several variables that influence the memorable touristic experiences related to food and restaurant. The results reveal that 14 finalized variables determine MFRE. Physical environment experience, food quality, and attractive food presentation were identified as top-level variables. Physical environment experience was found to be strongly dependent on other variables and has poor driving influence. Mirroring the findings of Walls (2013) and Khan \& Rehman (2016), this study has shown that the physical environment of the restaurant has an important and favorable influence on MFRE. Food quality and attractive food presentation had high driving and dependence power. Attractively presented food offered in a comfortable environment evokes emotional, physiological, cognitive, behavioral responses, which consequently enhance tourists' overall experiences. All these variables favorably engage tourists and leave a long-lasting impression.

Restaurant located in the mountainous destination can create a memorable gastronomy experience by offering the authentic destination foods prepared with traditional cooking methods and associated with hygiene \& cleanliness, lively atmosphere, and attractive design of the restaurant. The restaurant atmosphere includes music, smells, lighting, and heating. There are several pieces of evidence to advocate that a pleasant atmosphere has a strong influence on guest experiences. All these variables can create the 'genuine culinary experience' that visitor may seek out while visiting the destination. Authentic cuisines are considered most memorable, but the term 'authenticity' is entirely subjective. Usage of traditional preparation methods, the way of presentation, and locally grown ingredients can make a food authentic. Besides, restaurant settings and design can also add to the genuineness of the food 
offerings. Similar to the findings of Adongo et al. (2015), Chandralal \& Valenzuela (2013), and Sthapit (2017), the study advocate that authentic indigenous culinary experience augments the memorability of the touristic experience.

Further, healthy food \& ingredients, efficient service quality, human interaction experience, and displaying traditional socio-cultural objects in the restaurant contribute to the authenticity of food offering and novel restaurant experience. During traveling, visitors prefer food options that are healthy and prepared with local produce. Emphasizing on local ingredients and offering healthy food options add to the memorable gastronomy experiences (Hendijani, 2016). Presentation of socio-cultural objects demonstrate the lifestyles of locals, and destination-specific souvenirs can stimulate the sensory stimuli and complement the restaurant atmosphere. Efficient and error-free services are considered as one of the critical success features in the restaurant. Expert services can make mediocre consumption pleasurable, while substandard services can make excellent food terrible. Service quality and human interaction experience have reliable driving power, and therefore, restaurateurs must monitor the error-free services and meaningful social interactions to improve the overall MFRE.

Restaurant location, decoration, and service employee attributes are bottom-level variables in the ISM model of our study. These factors are found as strong drivers of MFRE, and help in stimulating authentic local food, providing excellent food \& service quality, and delivering novel gastronomy experience. In the case of destinations that are located in mountains and rural setting, it has been observed that visitors prefer restaurants based on their locations. Restaurants that are located in exotic and scenic surroundings, picturesque settings add to the overall impression of gastronomy and touristic experiences. Attractive decoration of restaurant also works as a motivating force to engage guests and creates an enduring image. Likewise, the professional abilities of employees, such as a way of communication, appearance, aptitude, and visitor-centric hospitality behavior, facilitate the overall social interaction experience. A warm welcome and individualized attention to guests help in improving the memorable touristic experience. Strengthening these bottom-line variables can improve the mid- 
level factors, which sequentially lead to the top-level factors and overall MFRE. Therefore, restaurateurs and concerned stakeholders such as tourism entrepreneurs, destination management organizations, and state tourism development boards should concentrate on strengthening the relationship connections recognized in this study. The outcomes of MICMAC analysis classified all the identified variables into four parts. This categorization would help the decision-makers select which variables to improvise in their restaurants that would lead to memorable experiences.

\section{CONCLUSION}

Food and restaurant attributes are believed as the strong determinants of the memorable touristic experience, positive destination image, distinctive advantage, superior reputation, and revisit intention. This study identified important dimensions of MFRE and established the relationships that exist among them in the mountainous destination. The resultant hierarchical structure offers restaurateurs a clear understanding of the various critical success factors of MFRE. This study has several implications for concerned stakeholders. First, the most critical drivers of MFRE were restaurant location, decoration, and attributes of restaurant employees. It exhibits that natural surroundings and interior decoration of restaurants should be appealing to visitors. The guest-centric attitude of restaurant employees and their hospitality attributes are vital for delivering novel experiences. Second, restaurateurs should also focus on offering authentic local food to visitors. The traditional methods of food preparation, usage of locally grown ingredients, and attractively presenting foods can add to the originality of the dishes. Third, hygiene and cleanliness, efficiency and timeliness of services, display of socio-cultural objects, restaurant atmosphere, and attractive design also contribute to the overall memorable tourist experience. The provided insights can be useful to tourism planners and practitioners to identify attributes most critical to MTE, highlight features that need attention and concentrate on the crucial attributes that have the potential of creating a competitive advantage for the destination.

\section{LIMITATIONS AND FUTURE DIRECTIONS}


There exist shortcomings of this study that warrant discussion. First, a memorable experience is a multidimensional model, and it is hard to believe whether identified variables have perfectly measured this. Second, MFRE variables in this study were identified through literature and professionals' judgment. There are chances that some other variables may have been ignored. In addition, the contextual relationship established among MFRE variable may have judgmental biases. Third, the proposed ISM model is not confirmed statistically. Future investigations could use SEM approach to test statistically significant relationships among MFRE variables. Lastly, MFRE has been examined in the context of mountainous destination of Uttarakhand, India only.

\section{References}

Adongo, C.; Anuga, S.; Dayour, F. Will they tell others to taste? International tourists' experience of Ghanaian cuisines. Tourism Management Perspectives, Vol. 15, No. July, 2015, pp. 57-64.

Alonso, A.D.; O'neill, M.; Liu, Y.; O'shea, M. Factors driving consumer restaurant choice: an exploratory study from the Southeastern United States. Journal of Hospitality Marketing \& Management, Vol. 22, No. 5, 2013, pp. 547-567.

Björk, P.; Kauppinen-Räisänen, H. Interested in eating and drinking? How food affects travel satisfaction and the overall holiday experience. Scandinavian Journal of Hospitality and Tourism, Vol. 17, No. 1, 2017, pp. 9-26.

Björk, P.; Kauppinen-Räisänen, H. Local food: a source for destination attraction. International Journal of Contemporary Hospitality Management, Vol. 28, No. 1, 2016, pp. 177-194.

Brakus, J.J.; Schmitt, B.H.; Zarantonello, L. Brand experience: What is it? How is it measured? Does it affect loyalty? Journal of Marketing, Vol. 73, No. 3, 2009, pp. 52-68. 
Chandralal, L.; Valenzuela, F. Exploring memorable tourism experiences: antecedents and behavioural outcomes. Journal of Economics, Business and Management, Vol. 1, No. 2, 2013, pp. 177-181.

Chang, R.C.Y.; Kivela, J.; Mak, A.H.N. Attributes that influence the evaluation of travel dining experience: When east meets west. Tourism Management, Vol. 32. No. 2, 2011, pp. 307-316.

Chao, S.-C. (2010). Exploration of local food selections in Lukang, Taiwan: Application of the means-end chain theory. (Doctor of Philosophy Dissertation), Texas: Texas Tech University. Retrieved from http://repositories.tdl.org/ttuir/bitstream/handle/2346/45275/Chao Shih-Chi Diss.pdf?sequence=1 [accessed 13 May 2019].

Chi, C.G.-Q.; Chua, B.L.; Othman, M.; Karim, S.A. Investigating the structural relationships between food image, food satisfaction, culinary quality, and behavioral intentions: The case of Malaysia. International Journal of Hospitality \& Tourism Administration, Vol. 14, No. 2, 2013, pp. 99-120.

Chow, I.H.; Lau, V.P.; Lo, T.W.; Sha, Z.; Yun, H. Service quality in restaurant operations in China: Decision- and experiential-oriented perspectives. International Journal of Hospitality Management, Vol. 26, 2007, pp. 698-710.

Correia, A.; Moital, M.; da Costa, C.F.; Peres, R. The determinants of gastronomic tourists' satisfaction: a second-order factor analysis. Journal of Foodservice, Vol. 19, No. 3, 2008, pp. 164-176.

Cracolici, M.F.; Nijkamp, P.; Rietveld, P. Assessment of tourism competitiveness by analysing destination efficiency. Tourism Economics, Vol. 14, No. 2, 2008, pp. 325-342.

Everett, S. Food and Drink Tourism: Principles and Practice. London: Sage, 2016. 
Gross, M.J.; Brown, G. An empirical structural model of tourists and places: Progressing involvement and place attachment into tourism. Tourism Management, Vol. 29, No. 6, 2008, pp. 1141-1151.

Henderson, J.C. Food tourism reviewed. British Food Journal, Vol. 111, No. 4, 2009, pp. 317-326.

Hendijani, R.B. Effect of food experience on tourist satisfaction: the case of Indonesia. International Journal of Culture, Tourism and Hospitality Research, Vol. 10, No. 3, 2016, pp. 272-282.

Heung, V.C.S.; Gu, T. Influence of restaurant atmospherics on patron satisfaction and behavioral intentions. International Journal of Hospitality Management, Vol. 31, No. 4, 2012, pp. 1167-1177.

Heung, V.C.S.; Wong, M.Y.; Qu, H. A study of tourists' satisfaction and post-experience behavioral intentions in relation to airport restaurant services in the Hong Kong SAR, Journal of Travel \& Tourism Marketing, Vol. 12, No. 2/3, 2002, pp. 111-135.

Kala, D.; Barthwal, S. Exploring tourist satisfaction on food and restaurant experience in mountainous religious destinations. International Journal of Tourism Policy, Vol. 10, No. 1, 2020, pp.1-22.

Kala, D. Examining the impact of food attributes and restaurant services on tourist satisfaction: evidence from mountainous state of India. Journal of Quality Assurance in Hospitality \& Tourism, Vol. 21, No. 4, 2020, pp. 430-453.

Kannan, G.; Pokharel, S.; Sasi Kumar, P. A hybrid approach using ISM and fuzzy TOPSIS for the selection of reverse logistics provider. Resources, Conservation and Recycling, Vol. 54, No. 1, 2009, pp. 28-36. 
Karamustafa, K.; Ülker, P. Impact of tangible and intangible restaurant attributes on overall experience: a consumer oriented approach. Journal of Hospitality Marketing \& Management, Vol. 29, No. 4, 2020, pp. 404-427.

Karim, S.A.; Chi, C.G.-Q. Culinary tourism as a destination attraction: An empirical examination of destinations' food image. Journal of Hospitality Marketing and Management, Vol. 19, No. 6, 2010, pp. 531-555.

Khan, I.; Rahman, Z. Brand experience anatomy in hotels: an interpretive structural modeling approach. Cornell Hospitality Quarterly, Vol. 58, No. 2, 2016, pp. 165-178.

Kim, J.-H.; Ritchie, J.R.B.; McCormick, B. Development of a scale to measure memorable tourism experiences. Journal of Travel Research, Vol. 51, No.1, 2012, pp. 12-25.

$\mathrm{Kim}, \mathrm{J}-\mathrm{H}$. The antecedents of memorable tourism experiences: The development of a scale to measure the destination attributes associated with memorable experiences. Tourism Management, Vol. 44, No. October, 2014, pp. 34-45.

Kim, J-H.; Youn, H.; Rao, Y. Customer responses to food-related attributes in ethnic restaurants. International Journal of Hospitality Management, Vol. 61, No. February, 2017, pp.129-139.

Kim, Y.G.; Eves, A.; Scarles, C. Building a model of local food consumption on trips and holidays: A grounded theory approach. International Journal of Hospitality Management, Vol. 28, No. 3, 2009, pp. 423-431.

Kivela, J.J.; Crotts, J. C. Tourism and gastronomy: gastronomy's influence on how tourists experience a destination. Journal of Hospitality \& Tourism Research, Vol. 30, No. 3, 2006, pp. 354-377. 
Liu, Y.; Jang, S.C. The effects of dining atmospherics: An extended Mehrabian-Russell model. International Journal of Hospitality Management, Vol. 28, No. 4, 2009, pp. 494503.

Mak, A.H.; Lumbers, M.; Eves, A. Globalisation and food consumption in tourism. Annals of Tourism Research, Vol. 39, No. 1, 2012, pp. 171-196.

Marinkovic, V.; Senic, V.; Ivkov, D.; Dimitrovski, D.; Bjelic, M. The antecedents of satisfaction and revisit intentions for full-service restaurants. Marketing Intelligence \& Planning, Vol. 32, No. 3, 2014, pp. 311-327.

Meng, F.; Tepanon, Y.; Uysal, M. Measuring tourist satisfaction by attribute and motivation: The case of a nature-based resort. Journal of Vacation Marketing, Vol. 14, No. 1, 2008, pp. 41-56.

Namkung, Y.; Jang, S. Does food quality really matter in restaurant? Its impact on customer satisfaction and behavioral intentions. Journal of Hospitality and Tourism Research, Vol. 31, No. 3, 2007, pp. 387-410.

Neuhofer, B.; Buhalis, D.; Ladkin, A. A typology of technology-enhanced tourism experiences. International Journal of Tourism Research, Vol. 16, No. 4, 2014, pp. 340350.

Oh, H.; Fiore, A.; Jeoung, M. Measuring experience economy concepts: Tourism applications. Journal of Travel Research, Vol. 46, No. 2, 2007, pp. 119-132.

Pine, J.; Gilmore, J.H. Welcome to the experience economy. Harvard Business Review, Vol. 76, No. 4, 1998, pp.97-107. 
Piqueras-Fiszman, B.; Jaeger, S.R. What makes meals 'memorable'? A consumercentric exploration. Food Research International, Vol. 76, Part 2, 2015, pp. 233-242.

Piramanayagam, S.; Sud, S.; Seal, P.P. Relationship between tourists' local food experiencescape, satisfaction and behavioural intention. Anatolia, Vol. 31, No. 2, 2020, pp. 316-330.

Quan, S.; Wang, N. Towards a structural model of the tourist experience: an illustration from food experiences in tourism. Tourism Management, Vol. 25, No.3, 2004, pp. 297305.

Ryu, K.; Lee, H-R.; Kim, W.G. The influence of the quality of the physical environment, food, and service on restaurant image, customer perceived value, customer satisfaction, and behavioural intentions. International Journal of Contemporary Hospitality Management, Vol. 24, No. 2, 2012, pp. 200-223.

Seo, S.; Yun, N.; Kim, O.Y. Destination food image and intention to eat destination foods: a view from Korea. Current Issues in Tourism, Vol. 20, No. 2, 2017, pp.135-156.

Seyfi, S.; Hall, M.C.; Rasoolimanesh, S.M. Exploring memorable cultural tourism experiences. Journal of Heritage Tourism, Vol. 15, No. 3, 2020, pp. 341-357.

Sims, R. Food, place and authenticity: Destination food and the sustainable tourism experience. Journal of Sustainable Tourism, Vol. 17. No. 3, 2009, pp. 321-336.

Sthapit, E.; Coudounaris, D.N. Memorable tourism experiences: antecedents and outcomes. Scandinavian Journal of Hospitality and Tourism, Vol. 18, No. 1, 2018, pp. 72-94.

Sthapit, E. Exploring tourists' memorable food experiences: a study of visitors to Santa's official hometown. Anatolia, Vol. 28, No. 3, 2017, pp. 404-421. 
Stone, M.J.; Soulard, J.; Migacz, S.; Wolf, E. Elements of memorable food, drink, and culinary tourism experiences. Journal of Travel Research, Vol. 57, No. 8, 2018, pp. 1121-1132.

Telfer, D.J., Wall, G. Strengthening backward economic linkages: local food purchasing by three Indonesian hotels. Tourism Geographies, Vol. 2, No. 4, 2000, pp. 421-447.

Thakkar, J.; Kanda, A.; Deshmukh, S. G. Interpretive structural modeling (ISM) of ITenablers for Indian manufacturing SMEs. Information Management \& Computer Security, Vol. 16, No. 2, 2008, pp. 113-136.

Tsai, C.T.S. Memorable tourist experiences and place attachment when consuming local food. International Journal of Tourism Research, Vol. 18, No. 6, 2016, pp. 536548.

Tung, V.W.S.; Ritchie, J.R.B. Exploring the essence of memorable tourism experiences. Annals of Tourism Research, Vol. 38, No. 4, 2011, pp. 1367-1386.

UNEP. Tourism and Mountains, report of United Nations Environment Programme, 2007. Retrieve from http://www.unep.fr/shared/publications/pdf/DTIx0957xPAMountainsEN.pdf [accessed 13 May 2019].

Walls, A.R. A cross-sectional examination of hotel consumer experience and relative effects on consumer values. International Journal of Hospitality Management, Vol. 32, No. March, 2013, pp. 179-192.

Widjaja, D.C.; Jokom, R.; Kristanti, M.; Wijaya, S. Tourist behavioural intentions towards gastronomy destination: evidence from international tourists in Indonesia. Anatolia, Vol. 31, No. 3, 2020, pp. 376-392. 
Wijaya, S.; King, B.; Nguyen, T.H.; Morrison, A. International visitor dining experiences: A conceptual framework. Journal of Hospitality and Tourism Management, Vol. 20, 2013, pp. 34-42.

WTTC. World Travel and Tourism Council Report - Travel and Tourism Economic Impact 2018 India, 2019, pp. 1-14.

Wu, C. H-J.; Liang, R-D. Effect of experiential value on customer satisfaction with service encounters in luxury-hotel restaurants. International Journal of Hospitality Management, Vol. 28, No.4, 2009, pp. 586-593.

Article info: Received 15/04/2020. Accepted 14/08/2020. Refereed anonymously. 